\title{
Gerrhonotus parvus Knight \& Scudday, 1985 (Squamata: Anguidae): New range extension and clutch size in the state of Nuevo León, Mexico
}

\author{
Javier Banda-Leal ${ }^{1^{*}}$, David Lazcano ${ }^{1}$, Manuel Nevárez-de los Reyes ${ }^{1}$ and Carlos Barriga-Vallejo ${ }^{2}$ \\ 1 Laboratorio de Herpetología, Facultad de Ciencias Biológicas, Universidad Autónoma de Nuevo León, San Nicolás de los Garza, Apartado Postal \\ 513, C.P. 66450 Nuevo León, México. \\ 2 Laboratorio de Ecofisiología, Facultad de Ciencias Biológicas, Universidad Autónoma de Nuevo León, San Nicolás de los Garza, F-96, C.P. 66450 \\ Nuevo León, México. \\ * Corresponding author. E-mail: javier_banda@hotmail.com
}

\begin{abstract}
We report a female specimen of Gerrhonotus parvus that represents a new record for the municipality of Santa Catarina, Nuevo León, Mexico. This species was known previously from only three localities in the state: the municipalitiy of Galeana; the type locality, Los Rayones, where only one specimen was registered; and San Isidro Canyon in Santiago, which previously was the northernmost locality and where the largest number of specimens have been observed and collected. This new record extends the range of the species $48.2 \mathrm{~km}$ northeast of the nearest known locality in Santiago. In addition, the specimen laid six eggs, which is the largest clucth documented so far. The type locality is located in a transition zone between pine forest (Pinus arizonica) and open gypsophilous scrub. However, the nature of the microhabitats at the other localities, including the northernmost one reported here, suggests that the species has a preference for dry limestone canyons.
\end{abstract}

DOI: $10.15560 / 10.4 .950$

The genus Gerrhonotus is endemic to North America and represented by six species: G. farri, G. infernalis, G. liocephalus, G. lugoi, G. ophiurus, and G. parvus. Of these, the most widely distributed is G. liocephalus in western and southern Mexico and $G$. infernalis in central and northern Mexico and southern Texas (Good 1994). The rest of the species are found in small areas and are known from only a few individuals. Gerrhonotus ophiurus is distributed in central and southwestern San Luis Potosí, eastern Querétaro, Hidalgo, Tlaxcala, Puebla, and mountainous areas of northern Veracruz (Lemos-Espinal and Dixon 2013); G. lugoi is isolated in the Basin of Cuatrociénegas, Coahuila (McCoy 1970); G. farri is found near Tula, Tamaulipas (Bryson and Graham 2010); and G. parvus is known only from the state of Nuevo León, in the municipalities of Galeana, Los Rayones, and Santiago (Banda-Leal et al. 2013). The three previously-mentioned species have a restricted distribution and very little is known about their biology. For G. lugoi, there is only a report of reproduction in captivity that describes the courtship behavior and litter size (Lazcano et al. 1993). For $G$. parvus, there are more details available about their natural history (Bryson et al. 2003). For G. farri, only the collecting data for a single specimen are known (Bryson and Graham 2010).

Although efforts have been made to understand the phylogenetic relationships of the species in the genus (Good 1988a, 1994, and Conroy et al. 2005), they remain unclear. Gerrhonotus parvus is known from the Sierra Madre Oriental in the state of Nuevo León, Mexico (Figure 1), originally reported for the municipality of Galeana in a

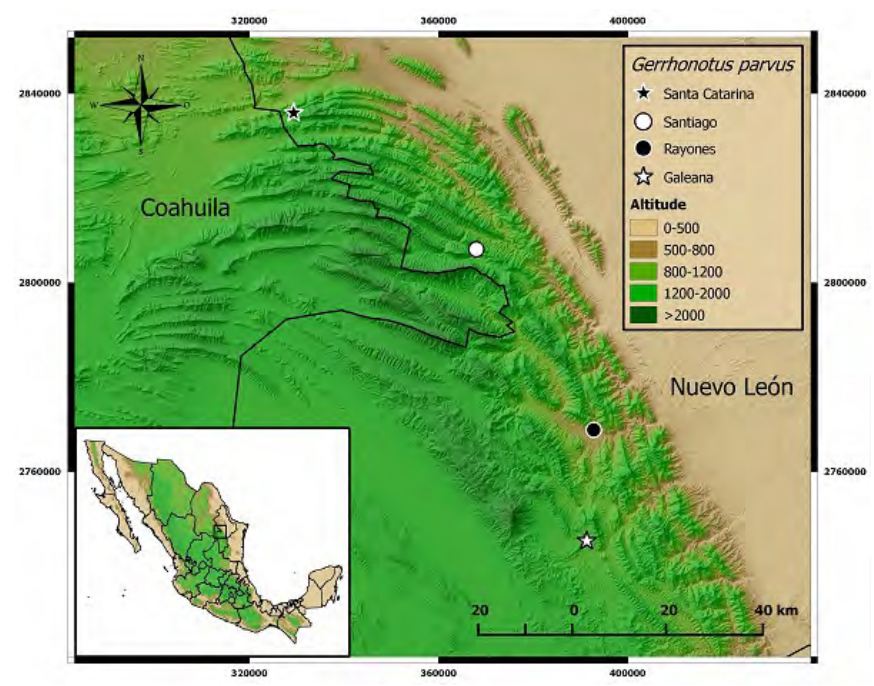

FIGURE 1. Geographic distribution of Gerrhonotus parvus, including the new locality reported for the municipality of Santa Catarina, Nuevo León, Mexico.

transition zone between pine forest (Pinus arizonica) and open gypsophilous scrub at altitude of $1650 \mathrm{~m}$ (Knight and Sccuday 1985) (Figure 2). The species has been recorded from the San Isidro Canyon, Santiago, Nuevo León. This canyon is at an elevation of $1,600 \mathrm{~m}$, runs east to west, is characterized by steep limestone walls covered with agaves (Agave sp), sotols (Dasylirion sp.), and scrub oaks (Quercus $s p$.), and has intermittent pools of water. The canyon bottom has piles of leaf litter with scattered large rocks (Banda-Leal et al. 2002; Bryson and Lazcano 2005) (Figure 3). The remaining record is from the canyon of 
Mireles, Los Rayones, Nuevo León, with a habitat similar to that of San Isidro Canyon, but with an elevation of 900 $\mathrm{m}$ (Conroy et al. 2005) (Figure 4).

This group is distributed in northeastern México along the Sierra Madre Oriental, a mountain range approximately $1,350 \mathrm{~km}$ long, paralleling the Gulf of Mexico, and terminating to the south in the Neovolcanic Axis, which divides North America from Central America.

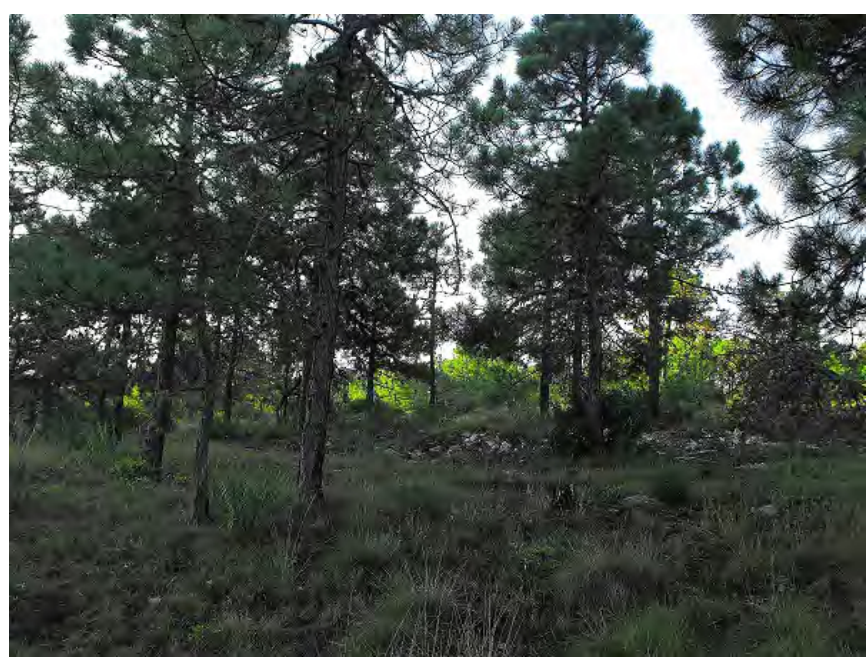

FIGURE 2. Type locality of Gerrhonotus parvus, transition zone between pine forest (Pinus arizonica) and open gypsophilous scrub in Galeana.

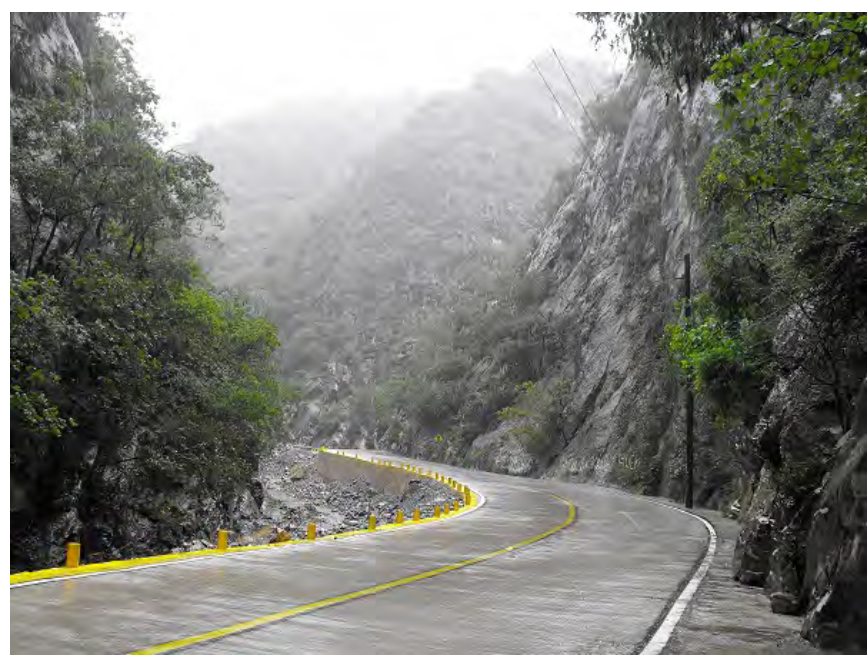

FIGURE 3. Limestone canyon with elements of Piedmont scrub in Santiago.

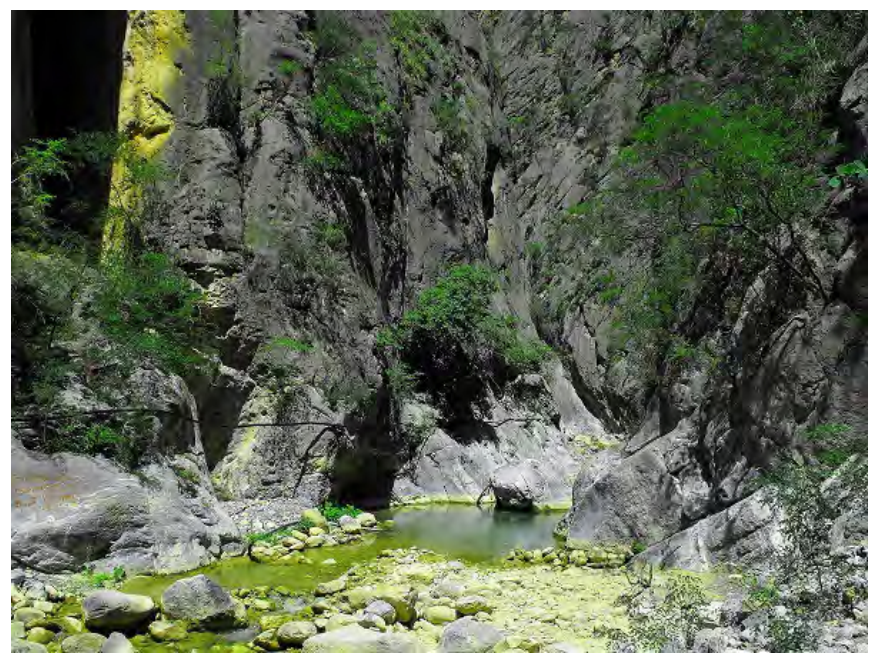

FIGURE 4. Limestone canyon with elements of Piedmont scrub in Los Rayones.
The cordillera runs through a large number of states, including Coahuila, Nuevo León, Tamaulipas, Texas, San Luis Potosí, Hidalgo, Tlaxcala, and others. The Pygmy Alligator Lizard inhabits only the states of Coahuila, Nuevo León, and Tamaulipas in Mexico.

Gerrhonotus parvus is characterized by a small, indistinct head with respect to the neck; slim body with short limbs and a tail length (TL) greater than the snoutvent length (SVL); head scales smooth and shiny; dorsal scales arranged in 16 longitudinal and 53 transverse rows; 12 longitudinal rows and 62 transverse rows on the venter; lateral fold formed by five or six rows of small granular scales; head grayish brown with irregularly distributed black spots and finely pigmented lips; gular area pearly white; dorsum grayish brown with pale gray transverse bands that are defined by dark edges, especially along the posterior edges of each band; pearly white belly; greyish brown tail, lighter than the trunk; and several transverse grey bands (Knight and Scudday 1985).

Scale counting is a tool to determine the genus and species (Waddick and Smith 1974). Gerrhonotus parvus is a small size lizard with a maximum total length (TL) of $130 \mathrm{~mm}$. (Banda-Leal et al. 2005) and $84.5 \mathrm{~mm}$ for females (Knight and Sccuday 1985). This species differs from its congeners by a combination of the following characters: small adult size, smooth dorsal scales, nasals in contact with medial fifth supraocular, suboculars separated from lower primary temporal by an upper lip, and wide pale crossbands on the tail. (Knight and Sccuday 1985).

While sampling for herpetofauna in the municipalities of García and Santa Catarina, Nuevo León (Figure 1), we collected in the municipality of Santa Catarina a female specimen of Gerrhonous parvus in the locality known as Cañon Reflexiones (Figure 5). This specimen collection was approved by the SEMARNAT (Secretary for Environment Protection Management), under permit number SGPA/ DGVS/01511/12 and 01589/12. The specimen (Figure 6) was deposited in the herpetological collection of the Universidad Autónoma de Nuevo León (UANL), catalog number UANL-7275. The specimen was identified using Good 1988. We measured (using vernier Helios accuracy $0.05 \mathrm{~mm}$ ) snout-vent length (SVL) and tail length (TL) and recorded the temperature of the body and microhabitat (using RayTek ST30 Pro Enhanced).

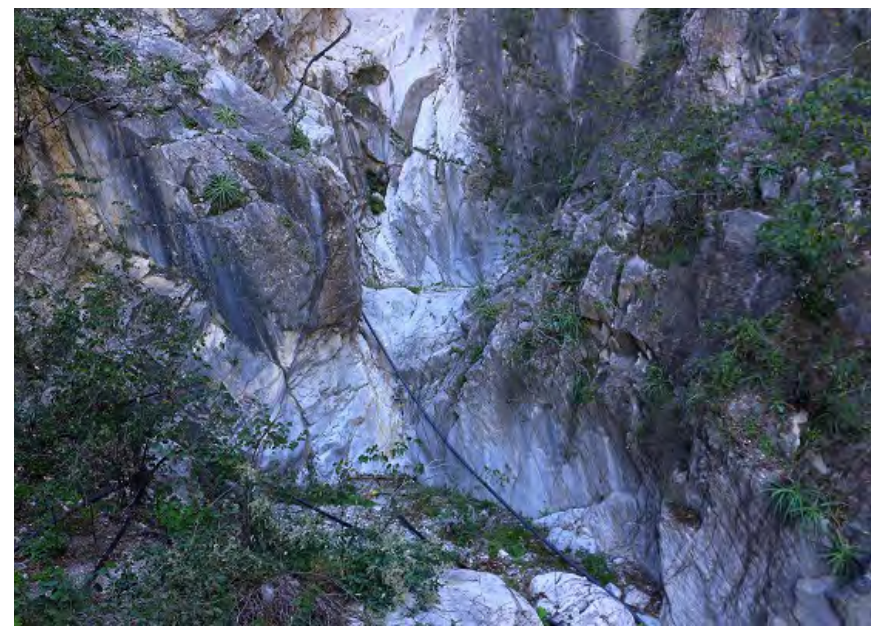

FIGURE 5. New locality of Gerrhonotus parvus in Santa Catarina. 


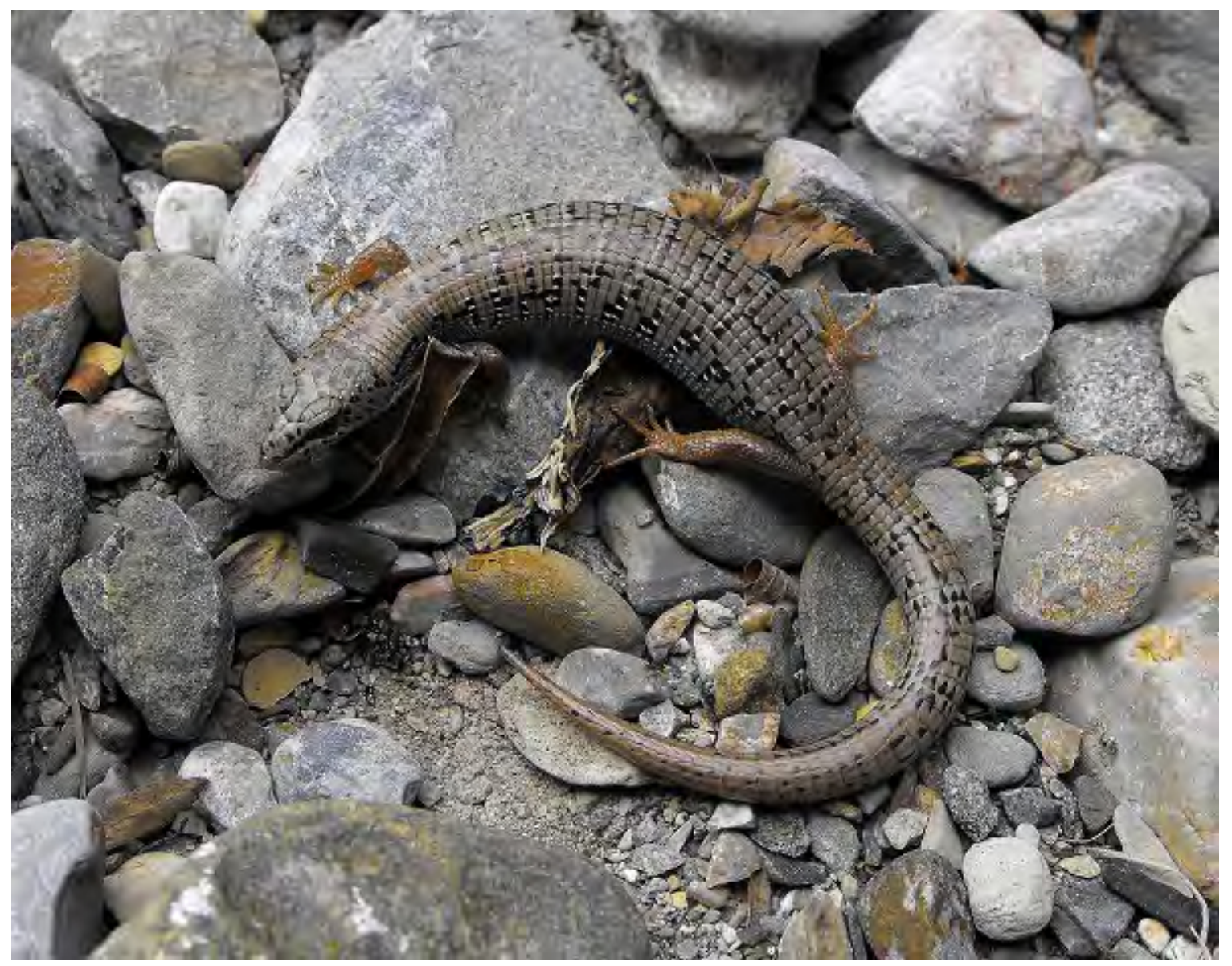

FigURE 6. Female of Gerrhonotus parvus (UANL-7275) collected in Santa Catarina.

We collected the specimen of Gerrhonotus parvus on 30 March 2012, in Cañon Reflexiones (25³7'50.68" N, $100^{\circ} 41^{\prime} 58.47$ " W, WGS84, $1650 \mathrm{~m}$ ), located 48.2 airline $\mathrm{km}$. northwest from the nearest locality recorded in the municipality of Santiago, Nuevo León (Figure 1). We found the lizard active on the wall of the canyon at 14:00 $\mathrm{h}$. The specimen had a SVL of $72.56 \mathrm{~mm}$ and a TL of $72.25 \mathrm{~mm}$ (incomplete). The ambient temperature was $24^{\circ} \mathrm{C}$, while that of microhabitat was $16^{\circ} \mathrm{C}$ and the body temperature (BT) $17^{\circ} \mathrm{C}$. Subsequently, on 9 May, the female laid six elliptical eggs that weighed on average $0.39 \mathrm{~g} \pm 0.01$ (0.37-0.41 g) and measured an average $13.06 \mathrm{~mm} \pm 0.05$ (12.54-13.57 $\mathrm{mm})$ in length and $7.27 \mathrm{~mm} \pm 0.05$ (7.18$7.36 \mathrm{~mm}$ ) in width. Unfortunately, they did not develop (Figure 7). This is a larger litter size than peviously reported for the paratype, which was 4 eggs (Knight and Scudday 1985). This determination was verified by Robert W. Bryson.

Cañon Reflexiones is quite narrow, made of limestone rock, with the presence of rosetophilous and piedmont scrub elements (Figure 5). At the base of the canyon, we found the folowing species of plants: Shrubby Bulls Eye (Gochnatia hypoleuca), Desert Willow (Chilopsis linearis), Texas Mountain Laurel (Sophora secundiflora), Barreta (Helietta parvifolia), and isolated individuals of Checkerbark Juniper (Juniperus deppeana). On the rocky walls of the canyon, we found the following species: Lechuguilla (Agave lecheguilla), Squid Agave (Agave bracteosa), as well Rock Palm (Brahea berlandieri) and several cacti (Mammillaria melanocentra, $M$. plumosa, Epithelantha unguispina, and several species of
Echinocereus). In the less rocky areas with a northeast exposition, we found Gregg's Pine (Pinus greggii).

This specimen of Gerrhonotus parvus represents the first record for the municipality of Santa Catarina, as well as the northernmost recorded for the species, extending its range $48.2 \mathrm{~km}$ northwest of the previously known localities (Banda-Leal et al. 2002). Currently, Gerrhonotus parvus is under the status of special protection by the NOM-059SEMARNAT (2010) and Endangered (B1 ab[iii] ver.3.1) by the IUCN (2013). The characteristics of the microhabitat of this site are very similar to those of the canyons of San Isidro and Mireles in the municipalities of Santiago and Los Rayones, which suggests that this species might have a preference for this type of habitat, rather than that of the type locality in Galeana, Nuevo León.

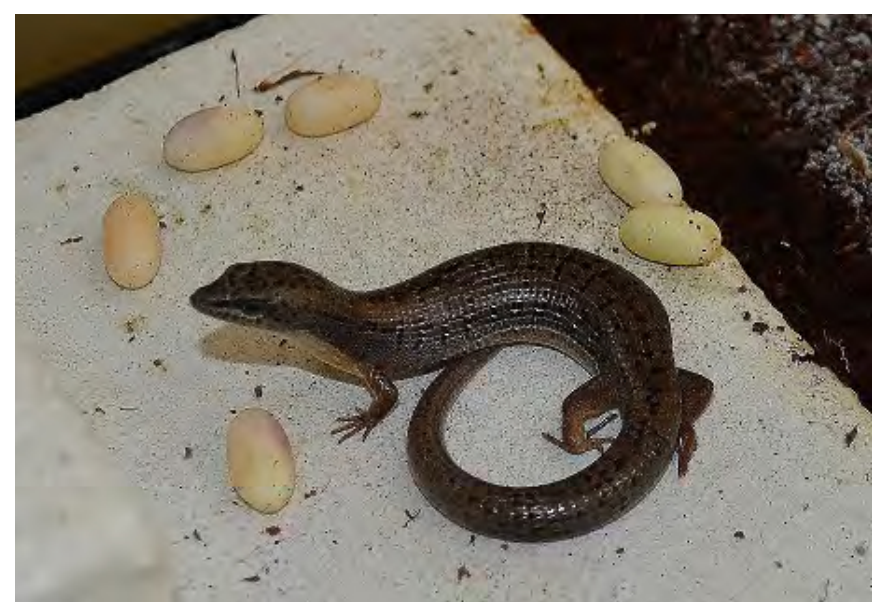

FIGURE 7. Litter of six Gerrhonotus parvus eggs. 
ACKNOWLEDGMents: We would like to thank the San Antonio Zoological Gardens and Aquarium and Los Angeles Zoo and Botanical Gardens for financial support for this study and SEMARNAT for issuing collecting permits and providing the most recent ones (Oficio Num. SGPA/ DGVS/0511/12 and 01589/13). We also would like to thank all the persons who participated in lab and field work, in particular Alejandro Huereca Delgado and Alejandra Rodriguez-Jaime and the authorities of Parque Nacional Cumbres de Monterrey. Special thanks to Robert L. Bezy and Larry D. Wilson for the review of this manuscript.

\section{Literature Cited}

Banda-Leal, J., D. Lazcano and M. Nevárez-de los Reyes. 2013. Notes on Mexican Herpetofauna 19: Herpetofauna Sympatric with Gerrhonotus parvus in San Isidro Canyon, Santiago, Nuevo León, Mexico. Bulletin of the Chicago Herpetological Society 48(2): 13-19. (http://www. chicagoherp.org/bulletin/48(2).pdf)

Banda-Leal, J., R. W. Bryson, Jr. and D. Lazcano. 2005. Gerrhonotus parvus (Pygmy Alligator Lizard). Maximum size. Herpetological Review 36(4): 449.

Banda-Leal, J., R. W. Bryson, Jr. and D. Lazcano. 2002. New record of Elgaria parva (Lacertilia: Anguidae) from Nuevo León, México. The Southwestern Naturalist 47(4): 614-615.

Bryson R.W. and M.R. Graham. 2010. A New Alligator Lizard from Northeastern México. Herpetologica 66(1): 92-98. (doi: http:// dx.doi.org/10.1655/09-012.1)

Bryson R. W., D. Lazcano, J. Banda-Leal, G. Castañeda-Gaitán y C. Garcíade la Peña. 2003. Historia Natural de la Lagartija Pigmea (Elgaria parva) Endémica de Nuevo León, México. Boletín de la Sociedad Herpetológica Mexicana 11(1): 21-22.

Bryson R.W. and D. Lazcano.2005. The Pygmy Alligator Lizard of Nuevo Leon, Mexico. The Reptilia European Herp Magazine (GB) No. (39): 69-72. April (http://www.reptilia.net/articulos_ing/039.pdf)

Conroy, C. J., W. R. Bryson, Jr., D. Lazcano and A. Knight. 2005. Phylogenetic placement of the Pygmy Alligator Lizard based on mitochondrial DNA. Journal of Herpetology 39(1): 142-147. (doi: 10.1670/0022-1511(2005)039[0142:PPOTPA]2.0.CO;2)

Good, D.A. 1988. Phylogenetic relationships among gerrhonotinae lizards, an analysis of external morphology. University of California Press (121): 1-139.

Good, D.A. 1994. Species limits in the genus Gerrhonotus (Squamata: Anguidae). Herpetological Monographs 8: 180-202. (http:// desertfishes.org/cuatroc/literature/pdf/Good_1994_species_ limits_Gerrhonotus.pdf)

IUCN. 2013. IUCN Red List of Threatened Species. Version 2013.2. Captured on 14 January 2014. Accessible at http://www.iucnredlist.org/.

Knight, R. A. and J. F. Scudday.1985. A new Gerrhonotus (Lacertilia: Anguidae) from the Sierra Madre Oriental, Nuevo León, Mexico. The Southwestern Naturalist 30 (1): 89-94.

Lazcano, D. Jr., A. Contreras-Arquieta and M. Nevárez de los Reyes. 1993. Notes on Mexican Herpetofauna 3: Reproductive Biology of Gerrhonotus lugoi an Anguid Lizard from the Cuatro-Cienegas Basin, Coahuila, Mexico. Bulletin Chicago Herpetological Society 28 (12): 263-265.

Lemos-Espinal J.A. and Dixon J.R. 2013. Amphibians and Reptiles of San Luis Potosí. Eagle Mountain Publishing. 312 pp.

McCoy, C. J. 1970. A new alligator lizard (genus Gerrhonotus) from the Cuatro-Cienegas Basin, Coahuila, Mexico. The Southwestern Naturalist 15(1): 37-44.

SEMARNAT. 2010. NORMA Oficial Mexicana NOM-059-SEMARNAT -2010, Protección ambiental-especies nativas de México de flora y fauna silvestres-categorías de riesgo y especificaciones para su inclusión, exclusión o cambio-lista de especies en riesgo. Diario Oficial de la Federación. Jueves 30 de Diciembre de 2010. (http:// www.profepa.gob.mx/innovaportal/file/435/1/NOM_059_ SEMARNAT_2010.pdf)

Waddick, J. W. and H. M. Smith. 1974. The significance of scale characters in evaluation of the lizard genera Gerrhonotus, Elgaria, and Barisia. Great Basin Naturalist 34: 257-266.

RECEIVED: February 2014

ACCEPTED: June 2014

Published ONLINE: September 2014

EDITORIAL RESPONSIBILITY: Philippe Kok 